http://www.jfas.info

\title{
COMPARATIVE STUDY OF THE ROLE OF EXPERT AND NON-EXPERT \\ LIBRARIANS, TO ATTRACT USERS, PUBLIC LIBRARIES AND PUBLIC \\ LIBRARIES OF TEHRAN MUNICIPALITY ART AND CULTURAL \\ ORGANIZATION OF TEHRAN
}

S. Ghaffari

Faculty member PNU

Published online: 15 February 2017

\begin{abstract}
Objective: A comparative study of the role of expert and non-expert librarians to attract users, public libraries and public libraries of Tehran Municipality Art and Cultural Organization of Tehran, is in 1395.
\end{abstract}

Research Methodology: This study is functional and causal-comparative. A questionnaire was used for data collection. According to methods of sampling and Morgan table from among 33 users of public libraries and covered by the Art and Cultural Organization of Tehran Municipality, the 6 districts of Tehran and using simple random sampling of 548 of the users as the sample were chosen.

Findings: The results show that, compared to professional librarians in non-specialist librarians, in terms of how to respond 93/7 percent and 88/8 percent in terms of how service users in how to deal with $45 / 28$ percent, better and more effective role to play. There is a significant difference in the level of error of $1 \%$.

Originality / value: In today's world, attracting the users, to study in libraries has gained momentum. This issue has caused librarians to attract users, the libraries have a sense of responsibility. Therefore, to further improve this problem, it should be a quantitative index, turned.

Author Correspondence, e-mail: author@gmail.com

doi: http://dx.doi.org/10.4314/jfas.v9i1s.683 
Keywords: Professional librarians, librarians lay, attract users, public libraries Cultural Organization, the Tehran municipality.

\section{INTRODUCTION}

Public libraries can be, the most important cultural centers - socially advanced societies today, to be considered. According to the audience area public libraries, the various segments of society, including, these centers fundamental role in the development of social, cultural and economic communities are responsible. And an important part of a fundamental transformation of society, are known.

Today, the key role of human resources and efficient in these organizations are not secret like other social institutions. Social responsibility is important that the public libraries, pay attention to the working conditions of the staff working in the library requires.

Log information to public libraries and the introduction of new technologies play a fundamental role in the development of information literacy and lifelong learning centers, new challenges faced by librarians working in public libraries put.

In this new situation, human resources, libraries, inevitably, to improve their work performance, and to respond to the changing needs of audiences centers. So that more users are attracted to libraries.

To accomplish this requires evaluation of librarians in terms of dealing behavior, their performance in terms of quantity and quality are the strengths and weaknesses, determine.

In fact, one of the library service evaluation methods to evaluate the users' willingness to libraries and their views, in particular, how the behavior and performance of expert and nonexpert librarians is.

So, with this investigation, the behavior and performance of expert and non-expert librarians that, to attract more users, can be strengthened and improved.

So that, users tend to participate more in libraries, have. It causes, promotion of culture, and also raises the level of knowledge and awareness of people.

Chehree, in his research, in the year 1392 shows that, in the libraries of Iran, most library professionals in technical services, and forces lay in the service sector of library work, as well as research reports Samadzadeh in 1393, this is fueling the user dissatisfaction and loss of quality, in technical libraries have been ineffective.

Focus, graduates working in the field of technical libraries, in our country, and the troops lay in the service sector; whereas, service - oriented professional librarian, phenomenon is questionable. 
The present study has tried this phenomenon, the roots of which, having expertise in attracting users distinction between librarian specialist and non-specialist librarian creates? And what group, more effectiveness, to attract users to their public libraries.

\section{RESEARCH OBJECTIVES}

\section{The overall goal of the research}

The aim of this study was to compare the role of expert and non-expert librarians in user uptake, in public libraries in Tehran.

Research objectives include:

1- Compare how the expert and non-expert librarians from the user perspective.

2- Comparison of expert and non - expert librarians response from the user perspective.

3-Compare the services offered expert and non-expert librarians from the user perspective.

4-Compare the amount of uptake expert and non-expert users from a user perspective.

5-Determination of attracting users to the library by the librarian expert from the user perspective.

6-Determination of attracting users to the library by non-specialist librarians from the user perspective.

7-determine the most effective factors to attract users by professional librarians from the user perspective.

8-determine the most effective factors to attract users by non-specialist librarians from the user perspective.

\section{Fundamental questions:}

The basic question is as follows:

The main question:

1-Whether between expert and non- expert librarians in terms of attracting users to the library from the user perspective about the difference there?

\section{Sub questions}

1-Is the behavior (communication skills) expert and non-expert librarians from the perspective of different users, is there?

2-some connection between the response (good word) expert and non - expert librarians from the user perspective, there are differences? 
3-Is the delivery of services (technical) expert and non-expert librarians from the user perspective, there are differences.

4-The absorption of library users, librarians expert, from a user perspective, what it is.

5-uptake library users, librarians lay, from a user perspective, what it is.

6-Are we among the factors that attract users by professional librarians, from a user perspective, there are differences.

7-Do we lay the factors that attract users by librarians from the user perspective there a difference?

\section{Research method}

This study, in terms of functional purpose attracts more users, the public libraries of Tehran, may be used. The study, causal-comparative, is a causal comparative method in a way, that can be, in which the researcher, according to the dependent variable (public library) to investigate the possible causes of the deals.

In this research, researchers, direct control of the independent variables (librarian expert and non-expert) does not. Because these variables are, by nature, are not manipulated and that, before the study took place.

The study population consisted of all users of public libraries and public libraries of Tehran Municipality Art and Cultural Organization, in 1395, that is.

The research sample of 22 districts of Tehran, randomly, 6 region, were selected. In these areas, in public libraries Cultural Organization of Tehran Municipality, the number of 37155 users and the public libraries in Tehran, the number of 47,632 users have existed, according to Morgan table, with $90 \%$ confidence, number of samples of each of the types of library General Organization of Tehran Municipality cultural and user 274 public libraries in Tehran, is .

According to the number of libraries, on the one hand, and increasing the accuracy, on the other hand, the sample size of 548 people, considered, was.

Data were collected using a questionnaire to evaluate the role of professional librarians and Non attract users, in public libraries in Tehran and Public Libraries \& Cultural Organization of Tehran Municipality, based on literature research and analysis taken place, and a questionnaire has been prepared.

And consists of two parts: Part A, respondents' demographic characteristics, including gender, age, education level and membership status of the user, is. And Part (b) has three 
sub-categories, in terms of communication skills, presentation skills and service skills to answer them.

In the questionnaire, questions 5 to 25 , the absorption rate referred to in the attitude of librarians, questions 26 to 30 , the absorption rate, in how they respond librarians, questions 31 to 35 , the amount of absorption, providing Accounting and question 36, relating to users, in attracting them.

The range is intended for the questions asked, the option at zero points, low points 1,2 average rating; high score of 3 , lot 4 points belong occurs.

-Gr test data collection (researcher) with going to the library questionnaire delivered to users and subjects is bound to a questionnaire about library specialist and a questionnaire about librarian lay the answer to why the researchers in this study proposes two questionnaires with the same content with the code specified unde the code a (for professional librarians) Code of $b$ (for non-specialist librarians) and provide each one Ows to complete the library was presented and in light of the fact that the only researcher of the meaning of the code information.

During the implementation of the survey participants, could, in the questionnaire, the questions raised. And tester, you must give them a call. Subjects, within 15 minutes to complete the questionnaire and then, to the test, deliver.

Overall, the 1096 questionnaire by 548 members, over a period of 4 weeks, was matched. Among which, 5 question naire, due to defects in response, has been excluded from the final analysis.

In the present study, data analysis, using descriptive statistical techniques and methods, as well as use of the inferential statistics, will be done.

To describe the data, the usual methods of descriptive statistics, such as frequency and percentage prepare the table, will be used. Also, to determine the factors that attract users, by expert and non-expert Friedman test results, will be presented.

In addition to reviews, the user is absorbed by each expert and non-expert groups, t-test results, separately, will be provided. And finally to compare the autonomous expert and non-expert, in each of the factors attracting and attract users, test results taffiliates, separately, will be reported.

In order to test the validity of the questionnaire is to librarians expert and non-expert Cronbach's alpha coefficient was used and the results obtained with the 31 questions, the 543 users surveyed indicated that alpha coefficient, for both librarians expert and nonexpert, 97 percent. 
The index is considered high. In addition, to assess the validity of the questionnaire mentioned using internal consistency, validity, results of correlation coefficient, each of these factors to attract users, librarians expert and non - expert, with scores of questionnaires showed that the correlation score of Inventory agent approach $(98 \%=\mathrm{r})$, how to respond $(89 \%=\mathrm{r})$ and how to provide services $(88 \%=\mathrm{r})$, by professiona 1 librarians, correlation score of the total, with operating approach, $(97 \%=r)$, how to respond $(87 \%=\mathrm{r})$ and how to provide services $(85 \%=\mathrm{r})$, by non-specialist librarians, the error is less than 01/0, are significant. Due to this, it can be concluded that the questionnaire to the high construct validity, is important.

\section{Findings:}

The first part - demographic information:

Table 1. The distribution and abundance of Sex users surveyed, in public libraries in Tehran, by type of library.

\begin{tabular}{|l|l|l|l|l|}
\hline total & General & $\begin{array}{l}\text { Municipality } \\
\text { Cultural } \\
\text { Organization }\end{array}$ & $\begin{array}{l}\text { Type Library } \\
\text { Statistical } \\
\text { Features }\end{array}$ & Sexuality \\
\hline 186 & 77 & 109 & Abundance & Man \\
\hline $34 / 3$ & $28 / 1$ & $40 / 5$ & Frequency & \multirow{2}{*}{ Female } \\
\hline 357 & 197 & 160 & Abundance & \multirow{2}{*}{ total } \\
\hline $65 / 7$ & $71 / 9$ & $59 / 5$ & Frequency & Abundance \\
\hline 543 & 274 & 269 & Frequency & \\
\hline 100 & 100 & 100 & &
\end{tabular}

The table now shows that, of the 543 users surveyed, 7/65 percent (357 users) female and $3 / 34$ percent (186 users) men, respectively. 
Table 2. The distribution and abundance of the age of the users surveyed, in public libraries in Tehran, by type of library

\begin{tabular}{|c|c|c|c|c|}
\hline total & General & $\begin{array}{l}\text { Municipality Cultural } \\
\text { Organization }\end{array}$ & $\begin{array}{l}\text { Type Library } \\
\text { Statisticat } \\
\text { Features }\end{array}$ & $\begin{array}{l}\text { The age of the } \\
\text { Year }\end{array}$ \\
\hline 370 & 195 & 175 & Abundance & \multirow{2}{*}{$25-15$} \\
\hline $68 / 1$ & $71 / 2$ & $65 / 1$ & Frequency & \\
\hline 155 & 73 & 82 & Abundance & \multirow{2}{*}{$35-26$} \\
\hline $28 / 5$ & $26 / 6$ & $30 / 5$ & Frequency & \\
\hline 13 & 3 & 10 & Abundance & \multirow{2}{*}{$45-36$} \\
\hline $2 / 4$ & $1 / 1$ & $3 / 7$ & Frequency & \\
\hline 4 & 2 & 2 & Abundance & \multirow{2}{*}{$55-46$} \\
\hline $0 / 7$ & $0 / 7$ & $0 / 7$ & Frequency & \\
\hline 1 & 1 & - & Abundance & \multirow{2}{*}{ More than 56} \\
\hline $0 / 2$ & $0 / 4$ & - & Frequency & \\
\hline 543 & 274 & 269 & Abundance & \multirow{2}{*}{ total } \\
\hline 100 & 100 & 100 & Frequency & \\
\hline
\end{tabular}

Studies in Table 2 indicates that, for a total of 543 users surveyed, 1.68 percent (370 users), with ages between fifteen to twenty - five years, and then 5 / 28 percent (155 users) aged between twenty - six to thirty - five years, respectively.

But, in the third degree, $4.2 \%$ (13 users) users, between thirty-six to forty - five years, and then $7.0 \%$ (4 user), between forty -six to fifty - five years old, have been. Finally, only 2.0 percent (1), more than fifty - six years old, had.

Table 3 shows the distribution and abundance of the education level of study, in public libraries, in Tehran, by type of library 
Table 3. The distribution and abundance of the education level of study, in public libraries, in Tehran, by type of library

\begin{tabular}{|c|c|c|c|c|}
\hline total & General & $\begin{array}{l}\text { Municipality } \\
\text { Cultural } \\
\text { Organization }\end{array}$ & $\begin{array}{l}\text { Type Library } \\
\text { Statistical } \\
\text { Features }\end{array}$ & Education \\
\hline 17 & 3 & 14 & Abundance & \multirow{2}{*}{ High school } \\
\hline $3 / 1$ & $1 / 1$ & $5 / 2$ & Frequency & \\
\hline 100 & 39 & 61 & Abundance & \multirow[b]{2}{*}{ Diploma } \\
\hline $18 / 4$ & $14 / 2$ & $22 / 7$ & $\begin{array}{l}\text { Abundance } \\
\text { Frequency }\end{array}$ & \\
\hline 12 & 5 & 7 & Abundance & \multirow[b]{2}{*}{ Know-how } \\
\hline $2 / 2$ & $1 / 8$ & $2 / 6$ & Frequency & \\
\hline 311 & 178 & 133 & Abundance & \multirow[b]{2}{*}{ Masters } \\
\hline $57 / 3$ & 65 & $49 / 4$ & Frequency & \\
\hline 90 & 44 & 46 & Abundance & \multirow[b]{2}{*}{ Masters } \\
\hline $16 / 6$ & $16 / 1$ & $17 / 1$ & Frequency & \\
\hline 13 & 5 & 8 & Abundance & \multirow[b]{2}{*}{ P.H.D } \\
\hline $2 / 4$ & $1 / 8$ & 3 & Frequency & \\
\hline 543 & 274 & 269 & Abundance & \multirow{2}{*}{ total } \\
\hline 100 & 100 & 100 & Frequency & \\
\hline
\end{tabular}

The above table of the 543 users surveyed 3/57 percent (311 users) initially has a bachelor's degree and a degree after 4/18 percent (100 users) have a diploma respectively.

This is the third level of 6.16 percent (90 users) has a master's degree and then $1.3 \%$ (17 users) have high school education level. But 4.2\% (13 users) users with a doctorate and finally $2.2 \%$ (12 users) has been an associate degree.. 
Table 4 shows the distribution and abundance of membership users surveyed, in public libraries in Tehran, by type of library

Table 4. The distribution and abundance of membership users surveyed, in public libraries in Tehran, by type of library

\begin{tabular}{|c|c|c|c|c|}
\hline total & General & $\begin{array}{l}\text { Municipality } \\
\text { Cultural } \\
\text { Organization }\end{array}$ & $\begin{array}{l}\text { Type Library } \\
\text { Statisticat } \\
\text { Features }\end{array}$ & $\begin{array}{l}\text { Membership } \\
\text { status }\end{array}$ \\
\hline 518 & 265 & 253 & Abundance & \multirow{2}{*}{ Member } \\
\hline 97 & $97 / 4$ & $96 / 6$ & Frequency & \\
\hline 16 & 7 & 9 & Abundance & \multirow{2}{*}{$\begin{array}{l}\text { Non- } \\
\text { members }\end{array}$} \\
\hline 3 & $2 / 6$ & $3 / 4$ & Frequency & \\
\hline 534 & 272 & 262 & Abundance & \multirow{2}{*}{ total } \\
\hline 100 & 100 & 100 & Frequency & \\
\hline
\end{tabular}

Table 4 indicates that, in general, the 534 users surveyed, 97 percent (518 users), a member of the library and only $3 \%$ (16 users), that are non-members.

Section II - Analysis of data:

Table 5. Affiliated groups $t$ test to compare how the expert and non-expert librarians, from a user perspective study.

\begin{tabular}{|l|l|l|l|l|l|l|l|}
\hline \multirow{2}{*}{$\begin{array}{l}\text { Probability } \\
\text { of error }\end{array}$} & $\begin{array}{l}\text { Degree } \\
\text { of } \\
\text { freedom }\end{array}$ & $\mathrm{T}$ & Number & $\begin{array}{l}\text { The } \\
\text { standard } \\
\text { error }\end{array}$ & $\begin{array}{l}\text { Standard } \\
\text { deviation }\end{array}$ & Average & $\begin{array}{l}\text { Statistical } \\
\text { features } \\
\text { The } \\
\text { librarian's } \\
\text { expertise }\end{array}$ \\
\hline $0 / 000$ & 542 & $40 / 51$ & 543 & $0 / 56$ & $12 / 96$ & $58 / 19$ & Expert \\
\cline { 4 - 8 } & & & & $0 / 53$ & $12 / 27$ & $29 / 74$ & $\begin{array}{l}\text { not } \\
\text { specialist }\end{array}$ \\
\hline
\end{tabular}


Findings from the study show that, the mean of attitude librarians specialist $(19 / 58=X)$, compared with an average of librarians in non-specialist $(74 / 29=\mathrm{X})$, in this context, more have been .

However, the results of the test $\mathrm{t}$ - affiliated groups in the field, revealed that, we mean the attitude of the two groups, a significant difference in the level of error of less than 01/0 there $\left(01 / 0 \mathrm{P}<, 51 / 40=\mathrm{t} \_542\right)$; thus it can be concluded that, from a user perspective study, in public libraries in Tehran, the attitude of professional librarians, compared with librarians lay in attracting users to the library, is more effective.

Table 6. Affiliated groups t test to compare how expert and non-expert librarians response from the user perspective study

\begin{tabular}{|l|l|l|l|l|l|l|l|}
\hline \multirow{2}{*}{$\begin{array}{l}\text { Probability } \\
\text { of error }\end{array}$} & $\begin{array}{l}\text { Degree } \\
\text { of } \\
\text { freedom }\end{array}$ & T & Number & $\begin{array}{l}\text { The } \\
\text { standard } \\
\text { error }\end{array}$ & $\begin{array}{l}\text { Standard } \\
\text { deviation }\end{array}$ & Average & $\begin{array}{l}\text { Statistical } \\
\text { features } \\
\text { The } \\
\text { librarian's }\end{array}$ \\
\hline $0 / 000$ & 542 & $37 / 43$ & 543 & $0 / 16$ & $3 / 64$ & $14 / 26$ & Expertis \\
\hline
\end{tabular}

From Table 6, it can be deduced that the average response obtained by way of professional librarians $(26 / 14=X)$, the average non - specialist librarians $(33 / 6=X)$, for a significantly more. In addition, $t$ affiliates test results indicated that, on average how response between the two groups, a significant difference in the level of error is less than $01 / 0$ ( $01 / 0 \mathrm{P}<, 43 / 37$ $=\mathrm{t} \_542$ ).

Due to this, it can be concluded that, in terms of users surveyed in Tehran public libraries, professional librarians how to respond, compared to non - specialist librarians, to attract users to the library more effective. 
Table 7. Test $t$, affiliates, to compare the way professional librarians and other professional services from a user perspective study

\begin{tabular}{|l|l|l|l|l|l|l|l|}
\hline $\begin{array}{l}\text { Probability } \\
\text { of error }\end{array}$ & $\begin{array}{l}\text { Degree } \\
\text { of } \\
\text { freedom }\end{array}$ & $\mathrm{t}$ & Number & $\begin{array}{l}\text { The } \\
\text { standard } \\
\text { error }\end{array}$ & $\begin{array}{l}\text { Standard } \\
\text { deviation }\end{array}$ & Average & $\begin{array}{l}\text { Statistical } \\
\text { features } \\
\text { The } \\
\text { libyarian's }\end{array}$ \\
\hline $0 / 000$ & 542 & $39 / 7$ & 543 & $0 / 17$ & $3 / 94$ & $14 / 69$ & Expertise \\
\hline
\end{tabular}

As the table above shows, the average obtained in the way services of professional librarians $(69 / 14=X)$, compared to an average of librarians lay $(81 / 5=X)$, in this case more.

The results of t-test, in this context, suggests that, between the two groups in the way of services listed, a significant difference in the level of error is less than 01/0 (01 / OP <, 7 / 39 $\left.=\mathrm{t} \_542\right)$. Accordingly, it can be stated that, from the perspective of users surveyed in Tehran public libraries, professional librarians on how to provide services to attract users to the library, to the non - specialist librarians, influential, is.

Table 8. Affiliated groups $\mathrm{t}$ test to compare the absorption rate expert and non - expert users, librarians, from a user perspective study

\begin{tabular}{|l|l|l|l|l|l|l|l|}
\hline $\begin{array}{l}\text { Probability } \\
\text { of error }\end{array}$ & $\begin{array}{l}\text { Degree } \\
\text { of } \\
\text { freedom }\end{array}$ & $\mathrm{t}$ & Number & $\begin{array}{l}\text { The } \\
\text { standard } \\
\text { error }\end{array}$ & $\begin{array}{l}\text { Standard } \\
\text { deviation }\end{array}$ & Average & $\begin{array}{l}\text { Statistical } \\
\text { features } \\
\text { The } \\
\text { librarian's }\end{array}$ \\
\hline $0 / 000$ & 542 & $42 / 87$ & 543 & $0 / 83$ & $19 / 32$ & $87 / 15$ & specialist \\
\hline & & & & $0 / 79$ & $18 / 42$ & $41 / 87$ & $\begin{array}{l}\text { not } \\
\text { specialist }\end{array}$ \\
\hline
\end{tabular}


As the above table indicates that, on average resulting from absorption of users by professional librarians $(15 / 87=\mathrm{X})$, Average attract users by librarians in non-specialist $(87 / 41=X)$, for a clear, more.

The test results $t$ affiliates, in this context, suggests that, between the average user uptake by the two groups, a significant difference in the level of error is less than $01 / 0(01 / 0 \mathrm{P}<, 87 /$ $42=\mathrm{t} \_542$ ). Therefore, it can be reported, investigated users in public libraries in Tehran, believed that, professional librarians, a far greater role in attracting users to the library, compared to non-specialist librarians have.

Table 9. Univariate $t$ test to determine the amount of users attracted by professional librarians, from a user perspective study

\begin{tabular}{|c|c|c|c|c|c|c|c|c|}
\hline $\begin{array}{l}\text { Probabilit } \\
\text { y of error }\end{array}$ & $\begin{array}{l}\text { Degree } \\
\text { of } \\
\text { freedo } \\
\mathrm{m}\end{array}$ & $\mathrm{T}$ & $\begin{array}{l}\text { Differencin } \\
\text { g means }\end{array}$ & $\begin{array}{l}\text { Assume } \\
\text { d mean }\end{array}$ & $\begin{array}{l}\text { Numbe } \\
\mathrm{r}\end{array}$ & $\begin{array}{l}\text { Standard } \\
\text { deviatio } \\
\mathrm{n}\end{array}$ & $\begin{array}{l}\text { Averag } \\
\mathrm{e}\end{array}$ & $\begin{array}{l}\text { Statistica } \\
1 \text { features } \\
\text { Variable }\end{array}$ \\
\hline $0 / 000$ & 542 & $\begin{array}{l}/ 33 \\
30\end{array}$ & $25 / 15$ & 62 & 543 & $19 / 32$ & $87 / 15$ & $\begin{array}{l}\text { The user } \\
\text { is } \\
\text { absorbed } \\
\text { by the } \\
\text { librarian } \\
\text { expert }\end{array}$ \\
\hline
\end{tabular}

For that, the user attracted by professional librarians, the questionnaire used in the study contained 31 questions in five degree Likert scale from 0 to 4 , respectively.

The scores range, between 0 to 124 , with an average hypothetical 62 , is. As can be seen, the mean, the uptake by users of professional librarians $(15$ / 87X =), compared with an average hypothetical $(62=\mathrm{X})$, about 15/25 unit, respectively.

However, univariate $\mathrm{t}$ test results showed that between average observed in the field and assumed there was no significant difference in the level of error of less than $01 / 0(01 / 0, \mathrm{P}$ $<33$ / 30t_542 =); the accordingly, it can be reported that the uptake of users by professional librarians significantly higher than average, and users of the public libraries in Tehran reported that professional librarians greatly in attracting users to the library affect. 
Table 10. Univariate $t$ test to determine the user is absorbed by non-specialist librarians, from a user perspective study

\begin{tabular}{|c|c|c|c|c|c|c|c|c|}
\hline $\begin{array}{l}\text { Probabilit } \\
\text { y of error }\end{array}$ & $\begin{array}{l}\text { Degree } \\
\text { of } \\
\text { freedo } \\
\mathrm{m}\end{array}$ & $\mathrm{t}$ & $\begin{array}{l}\text { Differencin } \\
\text { g means }\end{array}$ & $\begin{array}{l}\text { Assume } \\
\text { d mean }\end{array}$ & $\begin{array}{l}\text { Numbe } \\
\mathrm{r}\end{array}$ & $\begin{array}{l}\text { Standard } \\
\text { deviatio } \\
\mathrm{n}\end{array}$ & $\begin{array}{l}\text { Averag } \\
\mathrm{e}\end{array}$ & $\begin{array}{l}\text { Statistica } \\
1 \text { features }\end{array}$ \\
\hline $0 / 000$ & 542 & $\begin{array}{l}25 / 46 \\
-\end{array}$ & $-20 / 13$ & 62 & 543 & $18 / 42$ & $41 / 87$ & $\begin{array}{l}\text { The user } \\
\text { uptake } \\
\text { by non- } \\
\text { specialist } \\
\text { librarian }\end{array}$ \\
\hline
\end{tabular}

Since the absorption rate users by librarians lay in the questionnaire survey consists of 31 questions in Likert scale, five degrees from 0 to 4 and, therefore, the range of scores of between 0 to 124 , with an average hypothetical 62 , is.

Overall, the average obtained by the user attracted by non-specialist librarians $(87 / 41=X)$, than criterion $(62=\mathrm{X})$, about $13 / 20$ units, is less effective.

The results of univariate t-test, in this case showed that, between the two averages, a significant difference, The error is less than 01/0 (01 / 0P <, 46 / 25- = t_542); hence it can be stated that the absorption rate significantly less than the average non-specialist users by librarians and users study in public libraries in Tehran have believed that non-expert librarians, library users are effective in absorbing a small amount. 
Table 11. Friedman test to compare the factors that attract users by professional librarians, from a user perspective study

\begin{tabular}{|l|l|l|l|l|l|}
\hline $\begin{array}{l}\text { Significance } \\
\text { level }\end{array}$ & $\begin{array}{l}\text { Degree of } \\
\text { freedom }\end{array}$ & $X^{2}$ & Number & $\begin{array}{l}\text { Average } \\
\text { ratings }\end{array}$ & $\begin{array}{l}\text { Statistical features } \\
\text { Factors } \\
\text { acquisition }\end{array}$ \\
\hline $0 / 000$ & 2 & $903 / 63$ & 543 & $1 / 45$ & user \\
\cline { 3 - 5 } & \multirow{2}{*}{2} & & 3 & $\begin{array}{l}\text { How to respond } \\
\text { services }\end{array}$ \\
\hline
\end{tabular}

As the above table shows, in general, between the average ranking factors to attract users, by professional librarians, there are differences from each other.

So that the average rating of attitude $(X \mathrm{j}=3)$, compared with other factors to attract users, for a significantly more. Since the distribution of Friedman test, the degree of freedom d.f $=$ $\mathrm{K}-1$, almost square distribution, with the same degree of freedom, is the same.

The amount of the resulting Friedman test, chi - square value table will be compared. Because it is calculated that the amount of Friedman test $\left(63 / 903 \mathrm{X} \_3^{\wedge} 2=\right)$, the value of chi - square test table $\left(21 / 9 X^{\wedge} 2=\right)$, the degree of freedom 2 , the error is less than $01 / 0$, higher.

So it can be concluded that, among the factors that attract users by professional librarians, a significant difference existed.

With regard to this matter and considering the average rating of the results we find that users of the public libraries in Tehran, believed that the cause of the attitude of professional librarians, compared with other agents effective role in attracting the users.

Table 12. Friedman test to compare the absorption of non-expert users, librarians, from a user perspective study

\begin{tabular}{|l|l|l|l|l|l|}
\hline $\begin{array}{l}\text { Significance } \\
\text { level }\end{array}$ & $\begin{array}{l}\text { Degree of } \\
\text { freedom }\end{array}$ & $X^{2}$ & Number & $\begin{array}{l}\text { Average } \\
\text { ratings }\end{array}$ & $\begin{array}{l}\text { Seatures } \\
\text { Factory } \\
\text { acquisition }\end{array}$ \\
\hline $0 / 000$ & 2 & $892 / 39$ & 543 & $1 / 59$ & Attitude \\
\cline { 3 - 5 } & & & & $2 / 99$ & How to respond \\
\hline
\end{tabular}


As the findings above table indicates that, overall average rating factor between user uptake by non-specialist librarians, will considerably differ from each other.

So that the average rating of attitude $(99 / 2 \mathrm{Xj}=)$, compared to other factors attract users, more.

In addition, the results of Friedman test, in this context showed that the calculated value (39 / $\left.892 X^{\wedge} 2=\right)$, the value of chi - square test of crisis $\left(21 / 9=X^{\wedge} 2\right)$, the degree of freedom 2 , the error is less than 01/0, higher, and it can be stated that, among the factors to attract users, by non-specialist librarians significant difference existed.

Considering the average grade achieved in this case, we realized that users surveyed in the public libraries of Tehran, reported that, of the attitude of librarians lay, than the other factors mentioned, the role is far more effective in attracting users. 
Table 13. The distribution and abundance of comments about the study on the uptake and satisfaction, librarians, by Type Library

\begin{tabular}{|c|c|c|c|c|}
\hline total & General & $\begin{array}{l}\text { Municipality } \\
\text { Cultural } \\
\text { Organization }\end{array}$ & $\begin{array}{l}\text { Type } \\
\text { Library } \\
\text { Statistical } \\
\text { features }\end{array}$ & User comments \\
\hline 91 & 36 & 55 & Abundance & Librarian fluent in \\
\hline $22 / 8$ & $17 / 4$ & $28 / 5$ & Frequency & English \\
\hline 97 & 47 & 50 & Abundance & \multirow{2}{*}{$\begin{array}{l}\text { During the study, } \\
\text { the importance of } \\
\text { the region and } \\
\text { establishing peace } \\
\text { Tmrkzkarbr }\end{array}$} \\
\hline $24 / 3$ & $22 / 7$ & $25 / 9$ & Frequency & \\
\hline 96 & 53 & 43 & Abundance & \multirow{2}{*}{$\begin{array}{l}\text { The importance of } \\
\text { the physical } \\
\text { conference space } \\
\text { layout library }\end{array}$} \\
\hline 24 & $25 / 6$ & $22 / 3$ & Frequency & \\
\hline 53 & 18 & 35 & Abundance & \multirow{2}{*}{$\begin{array}{l}\text { General information } \\
\text { having high }\end{array}$} \\
\hline $13 / 2$ & $8 / 7$ & $18 / 1$ & Frequency & \\
\hline 24 & 24 & - & Abundance & \multirow{2}{*}{$\begin{array}{l}\text { roficiency in } \\
\text { research problems } \\
\text { and methods of } \\
\text { research }\end{array}$} \\
\hline 6 & $11 / 6$ & - & Frequency & \\
\hline 14 & 14 & - & Abundance & \multirow{2}{*}{$\begin{array}{l}\text { Introduction to } \\
\text { Scientific Research } \\
\text { Sites }\end{array}$} \\
\hline $3 / 5$ & $6 / 8$ & - & Frequency & \\
\hline 25 & 15 & 10 & Abundance & \multirow[t]{2}{*}{ Other cases } \\
\hline $6 / 2$ & $7 / 2$ & $5 / 2$ & Frequency & \\
\hline 400 & 207 & 193 & Abundance & \multirow{2}{*}{ total } \\
\hline 100 & 100 & 100 & Frequency & \\
\hline
\end{tabular}


As the table above shows, among the 269 users surveyed, 193 libraries of Tehran Municipality Art and Cultural Organization members, their opinions, expressed, that in-between 28.5 percent (55 users), Drdrj First, declare. Librarian mastering the English language, enhances and satisfaction to the library, to be.

And while, in the second place, 25.9 percent (50-user) show the teeth. The importance of focusing on clients while studying peace, the librarians to attract patrons to the library.

In the third place, 22.3 percent (43), paying attention to layout and physical space of the library, librarians, attract patrons to the library were considered.

But in the next level of 1.18 percent (35 users), users have believed that such public information, the librarians to attract increasing visitors to the library can be. Finally, $2.5 \%$ (10 users), users studied, Libraries and Cultural Organization, were referred to other cases.

But the 274 users surveyed, 207 public library user, expressed his opinion on this matter, which is in the midst of 6.25 percent (53 users) Followed by the importance of physical conference space layout enhances the Library librarians and satisfaction were known to the library.

While, then 22.7 percent (47 users), the importance of focusing on patients during the study and enhances the peace librarians to library patrons were considered.

But in the third place, $4.17 \%$ (36 users) users were shown. Mastering the English language enhances the librarian to library users, and Drdrj after 11/6 percent (24 users) reported that dominate the management issues and research methods librarian can attract the clients' satisfaction.

However, at $7.8 \%$ (18 users), users of public information, the librarians responsible for attracting visitors to the library, knowledge, and 2.7 percent (15 users), also pointed to other cases . And finally $8.6 \%$ (14 users), users of public libraries as had been the site of their familiarity with science - research and enhances the clients' satisfaction with the library.

In general, the 400 users to question 36 of the questionnaire, respondents were $3 / 24$ percent (97 user), first, were reported. The importance of user focus, and calm during the study by librarians to attract visitors to the library can be increased. And then 24\% (96 users) the importance of the layout and the physical space of the library by the librarian attract and satisfaction, were known to the library. 
While, in third place, 22.8 percent (91 users) dominate librarian in English and 13.2 percent (53 users) General information having top librarian, causing increased uptake of visitors to the library were considered. However, 2.6\% (25 users) users, on the other points, and 6\% (24 users), as well as management control issues and increased uptake of research librarians to library patrons had seen. Finally, 5.3\% (14 users) users surveyed declare that their familiarity with the scientific-research sites and enhances the clients' satisfaction with the library.

\section{CONCLUSION}

Research question: "Is the expert and non-expert librarians in terms of attracting users to the library from the user perspective about the difference there?" The analysis is the question of the questionnaire includes questions 5-35, according to Table 8 .

That is, the mean, the uptake by users of professional librarians 15/87 Average user uptake by non-specialist librarians $87 / 41$, for obvious more. Therefore, we can conclude that, the users of the public libraries in Tehran, believed that the librarian specialist, a far greater role in attracting users to the library compared to their non-specialist librarian.

Tahere olomi, is of the opinion that a well - qualified librarian must have specialized knowledge, have there and bibliographer. And know how to launch library. And finally attract more users to the library, and users are satisfied with them.

In response to the first question, the research is based on the "Is the treatment the expert and non expert librarians from the user perspective there a difference?" This question involves questions of the questionnaire is 5-25. Professional librarians in public libraries in Tehran treatment compared to non-specialist librarians are more effective in attracting users to the library.

Rene Evenson, in his book, it is stated that, recruiting or customer behavior and how to deal with them lies. In response to the second question is based on the "Is between expert and nonexpert librarians how to respond from a user perspective there a difference?" Analysis of the question, the questionnaire includes questions 26-30, is, according to Table 6 is the average obtained from the response of professional librarians 26/14 was significantly higher than the average for $33 / 6$ non - specialist librarians . 
Due to this it can be concluded that, in view of users of public libraries in Tehran in response to professional librarians, compared to non - specialist librarians to attract users to the library, have greater impact.

Rene Evenson, in his book, one of the factors in attracting people and clients, asking the right questions and the right answers to the questions mentioned above, ideas.

Crowley and Gylret (2002), in his study, at the University of Texas, found that the librarians who reluctance to users call, they pointed out that only users or employees, responded.

The biggest obstacles in getting help to users, are known. in this case more. Accordingly, it can be stated that, from the perspective of the users of the public libraries in Tehran, regarding services of professional librarians, to attract users, the library is more effective than nonspecialist librarians.

Rene Evenson, in his book, states that the provision of services, as appropriate, would enjoy doing as well as increased level of expertise in that field, and also to attract more people, and customers, is effective.

In response to the fourth question is based on the research that In response to the fourth question paper, based on the "absorption to library users, librarians expert, from a user perspective What is?" be reported that, in attracting users by professional librarians significantly more than average, in other words it can be said that users surveyed in public libraries reported that, professional librarians greatly in attracting users library, are effective.

Edward. Jay. Evans, in management techniques, it states that a librarian in the services it provides, as well as the needs of users ranging from training, as well as establishing peace in the library, technical competence have, and in this is a specialist field, in other words, a professional librarian should be.

In response to the fifth question, the study is that "uptake library users, librarians lay, from a user perspective, what it is?" Analysis of the question, the questionnaire includes questions 535 is, according to Table 10, the average obtained by the user attracted by non - specialist librarians out of a hypothetical $6287 / 41$ about 13/20 lower unit It is, hence, it can be stated that, attracted by librarians in non - specialist users, significantly, was lower than average. In other words, we can say, users of the public libraries in Tehran, have believed that nonspecialist librarian, a small amount, to attract users, the library will be effective. 
Taher olomi, the idea is now to increase the number of visitors to the library, the librarian must have expertise in this area. And a public information and education specialist, a librarian, is essential.

The result of this research can be, mainly, in many libraries that do not have the expertise, he observed.

In response to the sixth question, which is based on the study "whether among factors that attract users by librarian expert from the user perspective there a difference?" Analysis of the question, including questions 5-35, questionnaire. According to Table 11, is the average ranking of treatment $(3=(\mathrm{Xj}))$, compared with other factors to attract users, for a significantly more.

So it can be concluded that, among the factors that attract users by professional librarians, a significant difference existed. According to the results, we find that the average number of users studied at public libraries in Tehran, believed to have been responsible for management of professional librarians, compared with other factors, a more effective role in attracting users.

In response to the seventh question, the research is based on the "Is between user uptake of non specialist librarians from the user perspective, there is a difference?" Analysis of the question, the questionnaire includes questions 5-35 is, according to Table 12, the average number of collisions $(99 / 2=(\mathrm{Xj}))$, compared to other factors attract users, more. It can be stated that, among the factors to attract users, librarians non-specialist, a significant difference existed.

Considering the average grade achieved in this case, we realized that users surveyed in the public libraries of Tehran, reported that, of how librarians lay, than the other factors mentioned, the role is far more effective in attracting users, has it.

Rene Evenson, in techniques, to attract and retain customers, states that, to attract visitors to you, do the right thing. And ethical issues and to deal effectively with the stick, to attract more visitors. One can, mostly, it stated that, in the minds of people, especially users, mostly in learning and memory that remains, the attitude and commitment of librarians, to morals and good behavior with the user, is.

Finally, on the question 36 of the questionnaire, which the user's, about other factors that, in the questionnaire may be, is not listed. And users felt that, in these cases, to attract them to the library involved is presented. 
The results of answers to this question, in Table 13, have been reported. Items listed in this table, confirms that, in addition to that in the previous sections to attract users helped other items in priority order data, from a user perspective to below is raised, the librarians to comply with this and having these characteristics can more clients, attract.

1-importance of the user focus, while studying and establishing peace in the library.

2-importance of the layout and the physical space of the library, the librarian.

3-Fluency in English librarian.

4- having librarians, Top View.

5- Proficiency research issues and research methods.

6- their familiarity with the scientific and research sites.

\section{SUMMARY OF RESULTS}

In a general view, according to the results of the first part - demographic and Tables 1 to 4 , it can be concluded that the number of users of public libraries in Tehran, by gender, including 3/34 (User 186 ) males and 7/65 (357 users) are women.

In terms of age, class, more users, aged 25-15 years who referred $1 / 68$, the public library and the lowest users, people over 56 years, with 2.0 of users. And as educated and, thus, a high school diploma 1/3, 4/18 diploma, 2.2 BA, BS 3/57, 6/16 and 4/2 master their doctor.

$\% 97$ of users, from the library, and 3\%, non-members, and according to the results of the second part of the analysis of the data, and the results of Tables 4-5 to 4-12, it can be said that, since most patrons, libraries, according to the above-mentioned subjects, ages $25-15$, the young people are.

Mostly, according to statistics obtained a bachelor's degree, are. This, in my view, this research is important to them. It is the responsibility of librarians, for the young, is heavier.

Therefore, librarians, should benefit from the knowledge and expertise appropriate, its performance, increase. Which, to the researchers, but having a college education, majoring in Accounting and in-service training, can not be achieved. However, to the researchers, the government and the organizations, the recruitment of lay people, in libraries, prevent.

\section{Offers:}

\section{Practical suggestions:}


Practical suggestions, in order to maximize the impact of the study and performance of librarians in public libraries, which are then presented.

1-Pay more attention to the behavior and attitude of librarians at the time of hire.

2-selection and appointment of officials concerned and library professionals, sector and managerial positions in libraries.

3-accuracy, hiring specialists to complete the library staff and their appointment, on the right, with their power and interests.

4-adopt, appropriate and practical ways to evaluate librarians and recognize those who deserve more, have shown.

5-employing librarians, in doing that in the field, more skill and ability and the use of force expert in technical matters, in particular, the management of libraries.

6-Due to the transformation of the library profession and the role of the librarian, to identify ways to attract skills, is recommended. At appropriate intervals, meeting the specialized librarians, in one of the scientific community centers or classes, to be held.

7-importance of the training of librarians, in order to improve the quality of the classes and workshops at regular intervals and familiarizing librarians, skills attract users.

\section{REFERENCES}

1-Abram, H. (1379). "Cognitive Knowledge". Library and Knowledge Sciences, Tehran librarian.

2-Azkia, M. (1382). "Applied research methods in management". Third edition, Tehran: Islamic Azad University.

3-Ivenson, R. (2006). "101, quick and easy techniques to attract and retain customers." Translate Amir succeed. Tehran: expressive, 1390.

4-Babamiri, Ali (1381). "Evaluation of public libraries and proprietary". Qom province: Quarterly Message Library (Issue III): 86-94.

5-Behforuzi, Minoo (1370). "Check the status quo of public libraries in Tehran, the Ministry of Culture and Islamic Guidance". MA thesis, University of Educational Sciences, Tehran University.

6-Tadayon, Torshizi, M. (1374). "The situation of public libraries in Mashhad" . payan a graduate education, Tehran, Islamic Azad University, North Tehran Branch. 
7-German, Jay. E. (2001). "Accounting and professional values". Asadullah translator free. Tehran: librarian.

8-Chehreii, Ali Hope (1383). "Assessment of staffing and academic libraries in Kermanshah". Graduate thesis, Islamic Azad University of Tehran Research.

9-Everlasting, P. (1387). "History of Medical Education". Shiraz: electronic publication of Library, Archive and Information. Number Six: September and October 1387.

10-Soltani, Puri (1379). "Encyclopedia of Library and Information". Tehran: contemporary culture.

11-Samad Zadeh, G. (1383). "Check the quality of services provided in the library of the University of Sistan and Baluchistan", Librarian, 8 (1): 89-99.

12-Lieberman, David J. (2006). "Methods of attracting and persuading others". Randy translations Dlavy. Tehran: transcendence. 1390.

13-Hill, Nigel (2001). "Measuring customer satisfaction". Translator Reza Eskandari. Tehran Reza, 1384.

14-Yousefi, Khaled (1386). "A good librarian: Characteristics and Features". Tehran: Overview months.

15-AdomiE. E; Iwhiwhu B.E. (2004) "Users Levels of Satisfaction with Reserve Collection Services Instate University Library in Nigeria". Collection Build/ vol. 23 No.1/ Pp.39-44 (6).

16-Carrol, C. Edwars (1970). "The Professionalization Of Education For Librarianship: With Special Reference to the Years." Metuchen N.J.: the scare crow press.

17-Carr-sounders A.M. \& Wilson P.W. (1933). "The Profession."

18-Crowley, H Gilreath, C. (2002) "Probing User Perception Of Service Quality: Using Focus Group To Enhance Quantitative Surveys." Performance measurement and Mentrics, vol. 3 No. 2:78-84.

19-Dumont, Rosemary Ruhig (fall. 1991). "Ethics inLibrarianship: A Management Model Library Trends." Vol. 4, No 2, Pp150-201.

20-Elias, N (1964). "Professions" A Dictionary of the social sciences, Julius Gould \& William Lkolb. Compiled under thauspices of the united Nation Educational scientific and cultural organization. New York: the free press of Glencoe.

21-Elkin, Judith and Tom Wilson, eds. (1977). "Education ofLibrary and Information Professionals In The United Kingdom" London, England: Mansell. 
22-Fallis, Don (2007). "Information Ethics For Twenty-First Century Library Professionals", library Hitech, vol. 25. Iss: 1, Pp 23-36.

23-Hall, Richard H. (1969). "Professionalization and Bureaucratization." American sociological Review. 33:92-104.

24-Hansen show, Beth (2005), "Obtaining Users Opinions about Library, Assigning the Parts of Library Where Need to Be Developed, Registering the Pattern of Sat Is Faction Rate for Evaluating the Development Continuation".In sciences Library of Governors state university.

25-Houser, L.: Schrader, A.M (1978). "The Search fora Scientific Profession: Library Science Education intheU.S andCanada". Metuchen, N.J.: scare crow press.

26-Michie, Jonathan (2001). "Readers Guide tothe Social Sciences". Vol. 2. London; Chicago: Fitzory Dearborn publishers.

27-Nitecki, David; (1976). "Attitudes toward Automated Information Retrieval Services among RASD", R.O. 16 (2).

28-Nkere u wem, Edet E. (1992). "The Correlation between Job Attitudes and Work Behavior among the Staff in Academic Libraries in Nigeria". Information services and use, 12 (31,253261).

29-Rawski. Conrad H (1973). "Toward aTheory of Librarianship: Papers in Honor of Jesse Haok Shera". Metuchen, N.J.: the scare crow press. 14-55, 116-147.

30-Shera, Jesse H. (1972). "The Foundations of Education for Librarianship". New York Becker and Hayes Inc.

31-Websters New colligates Dictionary (1999). "American Webster". Spring field, Massachusetts, U.S.A: G \& C. Meriam Company.

\section{How to cite this article:}

Ghaffari S. Comparative study of the role of expert and non-expert librarians, to attract users, public libraries and public libraries of tehran municipality art and cultural organization of tehran. J. Fundam. Appl. Sci., 2016, 9(1S), 131-139. 